\title{
MOTIVES OF STRUGGLES IN KHALED HOSSEINI'S NOVEL A THOUSAND SPLENDID SUNS
}

\author{
Any Suharni and Susi Ekalestari \\ Faculty of Literature, Universitas Islam Sumatera Utara, Medan, Indonesia \\ e-mail: anysuharnisastra@gmail.com
}

Received: 25 Maret 2019

Accepted: 21 July 2019

\begin{abstract}
This study is an analysis of the aims of the protagonist's struggle in Khaled Hosseini's novel A Thousand Splendid Suns. The novel tells about a wife, the protagonist of the novel, who should live hard with a husband with bad temper. However, the protagonist by the name of Mariam keeps being a good wife for her husband. Furthermore, her husband has another wife. Unfortunately, the husband with his bad temper almost kills her. The protagonist should struggle to protect her husband's another wife as well. The analysis is conducted by descriptive qualitative method, in which the data are analyzed descriptively. Some theories, concepts and notions of struggle are applied in this study to support the analysis and finding. One of the theories adopted in this study is proposed Flexner and Fitzpatrict (1996: 9) who said that the concepts of struggle is permeated from the history, the labor movement, and the place of working woman. It implies that the struggle of woman is rooted from the history, the labor movement, and the place of working woman.
\end{abstract}

Keywords: motive, struggle, ambition, dreams, aims

\section{Introduction}

Struggle is something that is always found in human life. As human beings, everybody has to own an ambition or goal in his life, and to reach his goal he must struggle. No normal person lives without struggle. Nate (2012: 29) says that struggle is something that changes people. She empahizes that struggle will make people develop in their life. To change means to be different from one condition to a better one related to any aspects in life. Commonly, struggle is done to achieve one's ambition in his or her life or to get out from difficulty or to survive. In other words, there must be an aim in one's struggle.

The novel A Thousand Splendid Sun is written by Khaled Hosseni who was born on March 4, 1965 in Kabul, Afghanistan, the oldest of five children. The novel talks about the struggles of a wive who is the protagonist of the novel. She is a woman who should live in suffering that she should struggle in her life. The struggle of the protagonist is done dominantly in her household. A household is the togetherness among husband, wife, and children. As it is said by Clark (1997: 16) that there must be an unavoidably struggle under difficulties by being obliged to support the expenses of a wife and children. Therefore, the problem revealed in this study is related to the struggle of the protagonist named Mariam in the novel A Thousand Splendid Suns by Khaled Hosseni. The writers 
would like to reveal the aims of the protagonist's struggles in the novel A Thousand Splendid Suns by Khaled Hosseni. Then, this study focuses on the aims of the protagonist's struggle depicted in the novel. Hopefuly, this study can be beneficial either for the writers herself or the reader of this study. The benefit of this study is in the form of moral lessons in our life. This study adopts descriptive qualitative in its analysis. In other words, the data and the conclusion of this analysis are presented in the form or description.

\section{Literature Review}

Aim is "something that you are dreaming of and you are working so hard to achieve it" (Ouspensky, 2014: 76). In other words, aim is something that we are going to achieve in our life. However, he also emphasizes that an aim will only be formulated when someone excactly his or position is in a certain time. Someone should realize his or her condition or position in a certain time, then he or she is able to formulate certain aim related to his or her position. For example, at certain time, someone has much money but he or she has no certain thing to to do with the money. Then he or she will be able to formulate a new aim. There might be a lot of aim that can be formulated by such a condition. It can be going abroad, shopping, travelling, etc.

Aim is absolutely fulfiled by any efforts. Aim as described above refers to aim that is determined by certain condition and position at certain time. It means that certain condition of someone will determine his or her aim at that time. For example when someone is healthy and happy at certain time she or he might dream a traveling or other ones. Traveling as his dream is called aim. Then she or he will try to achieve it. On the other hand, when someone is in a bad condition or being sick. Then his or her ambition is to be recover from his or her sickness, they he or she will go to see a doctor to achieve his or her aim.

In educational field, aim is defined as "A general statement that provide direction or intent to educational action" (Wilson 1990: 92). Aim in this case is usually written in amorphous terms using words like: learn, know, understand. Thus, aim in this educational field refers to a target of leraning and understanding. This definition has close relationship to the understanding of aim as described above. However, it is in an educational field. When someone is in her or his education, in other words, someone in studying at school or college, then he or she has an aim on it. The aim is to get knowledge. Then he or she will learn to know and to understand to achieve his or her aim. It knowledge.

Talking about struggle, we will be faced by many perspective of thingking about it because struggle must be there in any aspect of life. For example, human beings will struggle in their life fo their ambition or for other purposes; animal will struggle to survive; and plants will struggle to grow in any natural condition. Nate (2012: 30) says:

"Some of my friends and I have been saying for a while stuff like

"struggle changes people" and about what we've called "developing"

people............in struggles, in terms of how people develop. ..I try

to lay out some ways that people in struggle can change. ..........about

some ideas about action and struggle changing people but how those changes are not automatic."

Nate clearly says that struggle changes people. We can capture the intention of the statement that struggle is an effort by human beings to change their life or to develop. The word develop means that persons will get better condition or an achievemant in their 
life. In other words, struggle is a positive action to achieve good condition or good ambition.

Other understanding of struggle is given by Lenin (1920: 79) who claims:

"It was, however, different with Bolshevism's other enemy within the working-class movement. Little is known in other countries of the fact that Bolshevism took shape, developed and became steeled in the long years of struggle against petty-bourgeois evolutionism, which smacks of anarchism, or borrows something from the latter and, in all essential matters, does not measure up to the conditions and requirements of a consistently proletarian class struggle."

Lenin emphasizes that struggle is related to labour or proletarian class. It happened long time ago when there were any action that had made the proletarian class threatened of living in descrimination because of the rules made by the superior class. This understanding of struggle has relationship to the protagonist' life among the rich people.

Noaman (2013: 125) says:

It's time for Muslims to use Ramadan to intensify the struggle for human liberation, not just from temptations of the flesh, but also from oppression and exploitation. - Couldn't a deeper form of empathy involve struggling against the conditions that produce poverty? This wouldn't come from a place of charity but from a place of solidarity, from a sense of oneness rooted in acknowledging our differences, but seeking to overcome them through struggle against structures of oppression and exploitation.

Noaman emhasizes sttruggle in a term of religious effort. Struggle means how human's ability in facing any temptation of the flesh, oppression and exploitation. In other words, struggle is the way how human beings face any temptation that might disturb their devotion to the Almighty, and how human beings avoid making any oppression or exploitation to other creature, aspecially to other people. This understanding of struggle may have little relationship to what is going to be analuzed in this study. However, this is quoted to be the comparison to the other definitions of struggle in this study.

Widyo et.al (1996: 164) say that struggle is a hard work to materialize dreams. Everyone in this world must have dream in his or her life. One's dream must be different from others. Then, one person will have different from other struggle to achieve the dream. However, struggle might be so hard, and so simple. It is called so simple because sometimes someone will get his or her dream undeliberately. While struggle is also so hard because someone will face many challenges either physically or mentally that need physical power or mental power such as bravery. It is in line with what is said by Krishnananda (1989: 69) that struggle might be fulfilled by various ways. In other words, the same dream might be realized with diffferent ways. Of course, it depends on the owner of the dream.

Dealing with struggle of woman, the writers adopt the theory of Flexner and Fitzpatrict (1996: 9) who claim that the concepts of struggle is permeated from the history, the labor movement, and the place of working woman. It implies that the struggle of woman is rooted from the history, the labor movement, and the place of working woman.

\section{Research Method}

This research uses qualitative method. According to Sandelowski (2000: 337), qualitative method is suitable when detailed descriptions of phenomena an a focus on the 
presentation of participants' dialogue with the researcher are desired. Qualitative research relies on qualitative data to investigate the research problem. Speziale and Carpenter, (2007: 80) state that a qualitative method matches my research problems because this study is discussed about the protagonist suffering as the phenomena in someone's life.

\section{Discussion}

As described previously that the protagonist by the name of Marian in this novel should live in suffering that she should struggle in her life. Mariam is married to a man named Rasheed who later marries another woman named Laila. However, Rasheed is not a good husband, and he is very cruel to both of them. Therefore, Mariam should struggle in her life.

\subsection{To Be a Good Wife}

As a wife, Mariam realizes that to be a good wife is gift to a husband. Therfore, Mariam tries her best to be a good wife for Rasheed. However, it is not easy for Mariam to be a good wife for Rasheed. It is hard for her to fulfill her duty as Rasheed's wife. It starts when Rasheed aks her to behave like a wife. It is seen in the following quotation:

Then one night he crushed his cigarette and instead of saying good night leaned against the doorway.

"Are you ever going to unpack that thing?" he said, motioning with his head towards her suitcase. He crossed his arms. "I figured you miht need some time. But this absurd. A week's gone and... Well, then, as of tomorrow mornin I expect you to start behaving lie a wife, Fahmidi? Is that Understood? (Hosseini, 2007: 63)

The quotation above shows that Rasheed wants Mariam to behave like a wife. Still, the way he tells his wife is too rough. It implies his anger. Actually, it is normal for a husband to have his wife behave well like a wife, but Rasheed must express his will in a good manner. Knowing this, Mariam feels so afraid.

The next day, Mariam starts to behave like a wife as her husband wants. She does what her husband has told her.

The next morning, after Rasheed left for work, Mariam unpacked her clothes and put them in the dresser. She draws a pail of water from the well and, with rag, washed the windows of her room and the windows to the living room downstairs. She swept the floors, beat the cobwebs fluttering in the corner of the ceiling. She opened the windows to air the house. She set three cups of lentils to soak in a pot, found knife and cut some carrots and a pair of potatoes. Left them to the soak. (Hosseini, 2007: 64)

The quotation above shows that the protagonist starts her struggle by cleaning up the house and cooking. However, it is still a strange activity for her, but she does it. What comes to her disappointment is when her husband comes home from work and says nothing as if she does not fulfill her duties as a good wife. She hopes that her husband sees what she has done. Therefore, she feels so unhappy with her husband's ignorance. It is seen in the following quotation:

When Rasheed came home that night, he brought with him a brown paper bag. Mariam was disappointed that he did not notice the clean windows, the swept floors, the missing cobwebs. (Hosseini, 2007: 6768) 
The quotation above shows that the protagonist feels disappointed with her husband because he does not notice what she has done as his wife.

Unfortunately, the more Mariam lives with Rasheed, the worse his temper is. Still, she should try her best to be his wife. Rasheed is really bad husband for her because he behaves badly to her. The following is one of the proofs of her husband's bad temper:

Rasheed didn't observe the fast. The few times he did, he came home in a sour mood. Hunger made him curt, irritable, impatient. One night, Mariam was a few minutes late with dinner, and he started eating bread with radishes. Even after Mariam put the rice and the lamb and okra qurma in front of him, he wouldn't touch it. He said nothing, and went on chewing the bread, his temples working, the vein on his forehead, full and angry. He went on chewing and srating ahead, and when Mariam spoke to him he lokked at her without seeing her face and put another piece of bread into his mouth. (Hosseini, 2007: 77-78)

The quotation above is one proof of Mariam's husband's cruelty. His bad temper is not physically hurt, but it breaks Mariam's heart. It happens in the fasting month. It is said that Rasheed gets angry because of Mariam's lateness for dinner one night. Then he behaves as if he is not an adult man. He treats Mariam badly because of his hunger. However, there must be good solution for such a kind of simple mistake done by a wife.

Mariam's husband has made her live in fear and torture because of his bad temper. The following is other proof that shows Rasheed's rough gabit towards Mariam:

It wasn't easy tolerating him talking this way toher, to bear his scorn, his ridicule, his insults, his walking past her like she was nothing...But after four years of marriage, Mariam was clearly how much a woman could tolerate when she was afraid.... She lived in fear of his shifting moods, his violate temperament, his insistence on steering even ...he would resolve with punches, slaps, kicks, ... (Hosseini, 2007: 97-98)

The quotation above shows that it is hard for Mariam to be Rasheed's wife. She should live with fear. Therefore, she struggles hard to tolerate her husband's bad temper. Even they have got married for four years. She tries to keep her marriage with Rasheed although she is punched, slapped, and kicked by her husband when he is in bad mood.

Rasheed is really a bad husband for Mariam. He gets angry easily for a nut mistake. It happens when he shakes the rice angrily from his fingers and pushes the plate away. Consequently, the rice is scattered on the floor. It is seen in the following quotation.

He shook the rice angrily from his fingers and pushed the plate away, spilling sauce and rice on the sofrah...

Mariam kneeled to the ground and tried to pick up the grains of the rice and put them back to the plate, but her hands were shaking badly. (Hosseini. 2007: 102)

Furthermore, the most irrational thing has been done by Rasheed to his wife is when he tries to force Mariam put some pebbles into her mouth. It is caused by something mistake according to Rasheed. It is about rice cooking. Rasheed says that Mariam does not cook the rice well eventhough it is done as it is usually made. What makes the protagonist surprised is that Rashed comes back after she finished collecting the grain of the rice. He takes the pebbles and force his wife to put it into her mouth. What on earth Rasheed has done to his wife. The following is the quotation. 
Then she heard the front door opening, and Rasheed was back in the living room. "Get up," he said. "Come here. Get up." He snatched her hand, opened it, and dropped a handful of pebbles into it. "Put these in your mouth."

"Stop it Rasheed, I'm..." His powerful hands clasped her jaw. He shoved two fingers into her mouth and pried it open, then forced the cold, hard pebbles into it. Mariam struggled against him, mumbling, but he kept pushing the pebbles in... "Now chew." He said. (Hosseini. 2007: 102)

The quotation shows that Mariam struggles to face her husband's anger. She takes the grain of the rice spilled by her husband from the ground and put them back to the plate. Rasheed just leaves the house after such action to his wife. Mariam as a wife just struggles to stop it without any attack to her husband. It is because she just wants to be a good wife.

However, Mariam still fulfils her duty as a wife. She wants to be a good wife. She serves her husband well in the time of dinner or lunch, although her husband treats her as a servant. The following the quotation to prove it:

He motioned impatiently with his hand, still looking at the girl, and Mariam passed him a napkin.

For years, Mariam had lokked on as he ate, the muscles of his temples churning, one hand making compact little rice balls...For years, he had eaten without looking up, without speaking, his silence condemning, as though some judgment were being passed, then broken by an accusatory grunt..., a one-word command for more bread, more water. (Hosseini. 2007: 205)

The quotation above shows that Mariam keep fulfilling her duty as a wife by serving what her husband needs and wants in eating time. It has happened for years, but she still does it as she can.

Other proof that proves Mariam's struggle to be a good wife is the following quotation showing that she obediently does what her husband orders her to do:

"Sit down," he said. He was lying on his bed, back to the wall, his thick, lomg legs splayed on the mattress. "Sit down before you faint and cut your head open."

Mariam felt herself frop onto the folding chaing beside his bed.

"Hand me that ashtray, would you?" he said.

Obediently, she did. (Hosseini, 2007: 207)

Mariam is seen too obedient to her husband. It is done because she is struggling to be a good wife for her husband, although her husband has done many cruel things to her. To obey husband is something that should be fulfilled by a wife, if she wants to be called as a good wife. It is what is done by Mariam, the protagonist in the novel.

Another quotation that proves Mariam's service to her husband is the following:

Brushing past Mariam, he said in a brusque voice, "I'm hungry. Get

Supper ready."

Mariam turned around and went to the kitchen to warm Rasheed's meal.

(Hosseini, 2007: 230)

The above quotation shows that Mariam serves her husband well although she has received many bad treatments from her husband. It is just to realize her wish, to be a good wife for her husband. 


\subsection{To Protect Her Husband's Another Wife}

The protagonist does not only struggle to be a good wife for her husband as described above, but also to protect her husband's co-wife. Actually, a co-wife is someone who has taken her husband because she has been her husband's second wife. Her husband's co-wife's name is Laila. However, their husband gets angry to Laila. He has hit her with his belt many times in front of her. It is seen in the following quotation:

She went to stop him, but he shoved her back and blew by her. Withoyt saying a word, he swung the belt at Laila. He did it with such speed that she had no time to retreat or duck, or even raise a protective arm...

Rasheed swung the belt again.

This time, laila shielded herself with a forearm and made a grab at the belt. She missed, and Rasheed brought the belt down again. (Hosseini, 2007: 337)

The above quotation shows that Laila is treated so bad by their husband. What has been done by her husband is inhuman. A husband should not treat his wife like an animal.

The protagonist witnesses what has been done to her husband's co-wife by their own husband directly. Even she could not count how many times Laila has been hit by a belt by their husband.

Mariam lost count of how many times the belt cracked, how many pleading words she cried out to Rasheed, how many times she circled around the incoherent tangle of teeth and fists and belt. (Hosseini, 2007: 338)

Even when Laila has tried hard to avoid her husband's bad temper, Rasheed has no intention to release her. Knowing this, Mariam tries to help her husband's co-wife. She struggles to uncurl Rasheed's fingers from Laila's neck when Rasheed wraps around Laila's neck. The following is the quotation:

They crashed to the ground, Rasheed and Laila, thrashing about. He ended up on top, his hands already wrapped around Laila's neck.

Mariam clawed at him. She beat at his chest. She hurled herself against him. She struggled to uncurled his fingers from Laila's neck. (Hosseini, 2007: 339)

The above quotation shows that the protagonist struggles to protect her husband's co-wife from death threat from their husband because her neck is wrapped by his fingers tightly.

Finally, the protagonist comes to her ultimate way to protect her husband's cowife. She takes a shovel and hits Rasheed's head at his temple. Then he dies. It is seen in the following quotation:

In the tollshed, Mariam Grabbed the shovel.

Rasheed didn't notice her coming back into the room. He was still on top of Laila, his eyes wide and crazy, his hands wrapped around her neck. Laila's face was turning blue now, and her eyes had rolled back. Mariam saw that she was no longer struggling. He's going to kill her, ... And Mariam could not, would not, allow that to happen. He'd taken so much from her in twenty-seven years of marriage. She would not watch him take Laila.

Mariam steadeied her feet and tightened her grip around the shovel's handle. She raised it. She said his name. She wanted him to see. 
"Rasheed."

He looked up.

Mariam swung.

She hit him across the temple. The blow knocked him off Laila.

(Hosseini, 2007: 339)

The quotation above shows that finally Rasheed dies because he is hit by Mariam by a shovel. It shows how hard the protagonist struggles to protect her husband's co-wife.

\section{Conclusion}

After the analysis of the aims of the protagonist's struggle in Khaled Hosseini's novel A Thousand Splendid Suns is conducted, it can be concluded that:

1. The protagonist, Mariam, has struggled in her life to be a good wife and to protect or safe her husband's another wife's life.

2. The protagonist has done her best in her struggle although it is quite hard for a wife to fulfil it towards such a kind of husband.

\section{References}

Clark, Anna. (1997). The Struggle for the Breeches: Gender and the Making of the British Working Class. Los Angeles: University of California Press.

Flexner, Leanor and Fitzpatrick, Ellen, (1996). Century of Struggle: The Woman's Right Movement in the United State. New York: The President and Fellows of Harvard College.

Grace. (1965). Response to literature. New York: McGraw - Hill Book Company Arnold.

Hull, Jum. (2014). Narrative First. In Dramatica Writers Workshop. 20-21 September 2014. Downtown Burbank, CA: Write Brother's Inc Offices

Krishnananda, Sri Swami. (1989). The Struggle for Perfection. India: The Divine Life Society.

Lenin Vladimir. (1920). Left-Wing Communism: An Infantile Disorder: The Struggle Against Which Enemies within the Working-Class Movement Helped Bolshevism Develop, Gain Strength, and Become Steeled. http://www.marxists.org/archive/lenin/works/1920/lwc/ch04.htm. (6 May 2014)

Milner, Max. (1992). Frued dan Interpretasi Sastra (Diterjemahkan oleh Apsanti Ds, dkk. dari Frued). Jakarta: Intermasa.

Nate. (2012). Struggle Change People. https://libcom.org/blog/struggle-change-people06012012. (6 May 2014)

Noaman. G. (2013). Cleansing Your Spirit, or Just Your Conscience? Towards a Class Struggle Ramadhan. http://basicsnews.ca/2013/07/cleansing-your-spirit-or-justyour-conscience-towards-a-class-struggle-ramadhan/. (6 May 2014)

Nugroho, Widyo, et.al. (1996). Ilmu Budaya Dasar. Jakarta: Gunadarma.

Ouspensky, P.D. From Aim to Conscience. http://wiki.answer.com/Q/Whatisan aims \#slide $=2 /(30$ Mei 2014)

Sandelowski, M. (2000). Focus on research methods. Whatever happened to qualitative description? Research in Nursing \& Health, 23(4) 334-340.

Speziale, H. S. \& Carpenter, D. R. (2007). Qualitative research in nursing: Advancing the humanistic imperative. (4th ed.) Philadelphia: Lippincott William \& Wilkins.

Wilson, Leslie Owen. (1990). Writing Curriculum. New York: Oxford University 